\title{
Lessons for farmer-oriented research: Experiences from a West African soil fertility management project
}

\author{
E. Suzanne Nederlof ${ }^{1}$ and Constant Dangbégnon ${ }^{2}$ \\ ${ }^{1}$ Royal Tropical Institute (KIT), Amsterdam, The Netherlands; ${ }^{2}$ International Center for Soil Fertility and Agricultural Develop- \\ ment-Africa (IFDC-A), Lomé, Togo
}

Accepted in revised form May 4, 2006

\begin{abstract}
Donors, scientists and farmers all benefit when research and development projects have high impact. However, potential benefits are sometimes not realized. Our objective in this study is to determine why resource-poor farmers in Togo (declined to) adopt recommended practices that were promoted through a multi-organizational project on soil fertility management. We examine the processes and outcomes related to the adoption process. The project was undertaken in three villages in the Central Region of Togo in West Africa. The development and research processes that took place during the implementation of the project were critically analyzed using a conceptual framework that may be useful for improving the impact of future participatory projects. At the macro level, opportunities for innovation were not deliberately explored with participating farmers and other village members; consequently "pre-analytical choices" made during the planning phase resulted in practices that resource-poor farmers were, for a variety of reasons, unable or unwilling to adopt. From the outset, donors and scientists focused on soil fertility management, but failed to take into account the wider economic context within which soil fertility management took place. This was a major obstacle to the subsequent adoption of recommended management strategies. Scientists and donor partners measured the success of the Project in terms of crop productivity, but farmers' choices were influenced by a complex mix of socio-economic, political and technical factors. We also illustrate the importance of selecting appropriate categories of farmers for a particular experiment. We conclude that for participatory research and development projects to be successful, it is not enough to develop technologies that "work" in a technical sense. In order to be scaled up and widely implemented, such technologies must also meet a variety of needs of resource-poor farmers and be acceptable from a socio-cultural point of view.
\end{abstract}

Key words: Agricultural research, Farmer livelihoods, Participatory development, Pre-analytical choice, Resourcepoor farmers, Soil fertility, Technology development, Togo, West Africa

Abbreviations: CoS - Convergence of Sciences; ISFM - Integrated Soil Fertility Management; NGO - Non Governmental Organization; PCC - Project Co-ordination Committee; PTD - Participatory Technology Development

Suzanne Nederlof holds a PhD in Communication and Innovation Studies from Wageningen University in the Netherlands. After finishing her MSc. degree in Development Sociology at the same university she worked at a research project in Burkina Faso and at the International Center for Soil Fertility and Agricultural Development (IFDC) in Togo. Subsequently, she was based at the FAO regional office for Africa in Ghana, assigned to the Convergence of Sciences Program. She conducted the fieldwork for this article during that period. She completed her $P h D$ research on agricultural research with a scholarship from the Netherlands Organization for Scientific Research. She is currently employed as an advisor in rural innovation at the Royal Tropical Institute (KIT) in Amsterdam, The Netherlands.

Constant Dangbégnon worked for several years (1990-1998) on Inter-University Cooperation (Benin, the Netherlands and Israel) in the area of indigenous knowledge and the soft side of natural resource management. This work constituted the basis of his PhD from Wageningen University in The Netherlands. He joined IFDC - Africa Division in Lomé (Togo) in June 1999 as a socio-economic extension specialist in the Input Accessibility Program (IAP). 


\section{Introduction}

Several authors have expressed skepticism as to whether attempts made by agricultural research to improve the sustainability of land use for West African farmers have been successful (Chambers and Jiggins, 1987b; Pretty, 1995; Mutimba, 1997; Bie, 2001; Stoop, 2002). The "Green Revolution" in irrigated rice in Asia was successful mainly because it was based on the introduction of high-yielding varieties, which needed inputs such as irrigation, pesticides, and fertilizers in order to be productive. In this particular context it was possible to make the environment fit the genotype (Castillo, 1998). However, in many African contexts, agriculture is too heterogeneous for such an approach. African agriculture has been described as risk-prone, highly diverse, and rain-dependent (Reijntjes et al., 1992). In addition to biophysical constraints, African farmers face low market prices. The availability of cheap agricultural products from regions using Green Revolution technologies and from industrial countries has driven prices down, worsening the situation for African smallholders.

Under such conditions, what benefits may research realistically contribute to agricultural development? The impressive literature on the non-adoption of research outputs (e.g., Rogers 1995; Scheuermeier et al., 2004) suggests that non-adoption may be explained by farmers' lack of knowledge and scarce resources, non compatibility of the technologies promoted with farm conditions and farmers' goals, and the limited political influence of resource-poor farmers on the research process. These problems have been addressed by the Training and Visit approach (Chambers and Jiggins, 1987a), Farming Systems Research (Collinson, 2000; Dixon et al., 2001), on-farm research (Chambers, 1990, 1994, 1997; Werner, 1996; Mutsaers et al., 1997), and participatory technology development methods (Rhoades and Booth, 1982; Pretty et al., 1995; Vereijken, 1999). A more recent explanation for the limited impact of research on the livelihoods of resource-poor farmers is that researchers alone cannot grasp the complexity and dynamics of local situations (Pound et al., 2003; Scheuermeier et al., 2004). This recognition resulted in the development of different approaches, for example, Participatory Innovation Development (Scheuermeier et al., 2004), Enabling Innovation (Douthwaite, 2002), partnership building for advancing Participatory Technology Development (PTD) (Van Veldhuizen et al., 2003), Local Agricultural Research Committees (Ashby et al., 2000), Farmer Field Schools (van de Fliert, 1993; Pontius et al., 2002; CIPUPWARD, 2003) and the Convergence of Sciences (CoS) approach (Hounkonnou et al., in press). ${ }^{1}$ Van de Fliert and Braun (2002) also address this issue and state that it is increasingly accepted that farmers should play an important role in research, development, and extension.

The present study aimed to fine-tune a client-oriented framework for agricultural research, developed within the $\mathrm{CoS}$ program, in order to support the development of criteria and procedures for better stakeholder collaboration. Deliberate, careful negotiation and interaction with all stakeholders was considered necessary for agricultural research outcomes to be efficient and fit the needs and opportunities of farmers. We assumed that the context for resource-poor farmers cannot be changed in order to meaningfully apply an innovation; therefore, it was inescapable that innovations produced by science needed to fit the existing ecological, social and economical context.

The research and development project on Integrated Soil Fertility Management (ISFM) carried out in Togo was used as a case study to analyze the impact of choices on research design and processes. ${ }^{2}$ Giampietro $(2003,30)$ calls these choices "pre-analytical" and defines them as the "choice of relevant goals, variables, and explanatory dynamics for the selection of an explanatory model." To explain the concept, he uses Mandelbrot's (1967, in Giampietro, 2003) example: if you want to know the length of Britain's coastline, you had better agree on the scale of the map that is to be used, because the scale will strongly affect the result. Critical issues emerging from the case were analyzed in order to gain insight into the relationships and dynamics underpinning the effectiveness of agricultural research that was intended to enhance the livelihoods of resource-poor farmers. These critical issues provide micro case studies within the larger case study, revealing the often transformative effect of the relationship between the context, the activities, and outcomes.

We deliberately emphasize farmers' perspectives because farmers were the intended beneficiaries. The case reported in this article aims to draw lessons regarding the factors needing to be considered in the design of research intended to benefit resource-poor farmers; hence, this article reports "research on research."

\section{Conceptual framework}

The focus of this study is the research process rather than the research outcomes. An initial conceptual framework (Nederlof, 2003) was developed on the basis of a literature review. To validate the initial framework, tools such as brainstorming, validation workshops and discussion sessions, both with individuals and with groups, were organized with $\mathrm{CoS}$ and other scientists. In order to develop a research process that benefited resource-poor farmers, we proposed five criteria and procedures (see also Röling et al., 2004). ${ }^{3}$ 
1. Research takes into account existing opportunities or potential for innovation at a macro level. This implies a thorough understanding of the context and relevant stakeholders before the start of the project.

2. Research is grounded in the opportunities, needs and expectations of intended beneficiaries. This means anchoring research activities in local conditions, including stakeholder demands and needs, specifically those of resource-poor farmers.

3. Research results in design systems that work under the conditions facing farmers. Hence, the (agricultural) innovation or technology developed should be feasible and efficacious given the farming system and field conditions.

4. Research results in design systems that are acceptable and appropriate for resource-poor farmers. This implies that the innovation or technology not only yields the desired results but also fits the culture, preferences, traditions, personal circumstances and priorities of resource-poor farmers.

5. Research develops innovations that can be scaled up. Thus, the technologies or innovations developed should potentially have an impact beyond that of the farmers initially involved and past the duration of the original project.

In discussing these criteria, certain proxies or indicators were used because the criteria in and of themselves were not "measurable." These proxies are crosscutting, meaning that they are relevant to more than one of the criteria:

1. Participation of stakeholders in "platforms" to engage in collaborative learning. Pretty (1994, 1995; Pretty et al., 1995) developed a ladder distinguishing different types of participation. He argued that for sustainable development, nothing less than interactive participation was required. ${ }^{4}$ Participation is a tool to facilitate learning that increases the countervailing power of farmers over the research process (the democratization of science, c.f. Funtowicz and Ravetz, 1993). Johnson et al. (2003) assessed the impact of participatory methods on research usefulness and found that participation resulted in greater economic impact and more relevant innovations, mainly when participation was implemented at an early stage in the research process. In the late seventies, Morss (1976) made similar observations.

2. Socio-cultural factors that are pertinent to communities, the production system, and technical aspects.

3. There is an interface between technical / biological and social issues.

4. Issues related to the wider context affecting farmers' livelihoods (e.g. marketing possibilities).

5. The assumption that farmers have veto power (Röling et al., 2004); therefore, research must be negotiated with farmers. The design of research processes is at the interface between science and the veto power of farmers. Hence, the pre-analytical choices made (e.g., regarding hypotheses, topic, type of benefit to be achieved) can hamper the impact of the research if not negotiated with farmers.

In our case study, stakeholders, including farmers, were asked to evaluate the project and related issues. This allowed the framework to be fine-tuned as the study progressed. The proxies thus emerged during the case study and should therefore be considered an outcome of the present study.

\section{Methods}

We opted for a qualitative research approach due to the exploratory, conceptual and constructivist character of the study (see Guba and Lincoln, 1989; Denzin and Lincoln, 1994). Two principles guided the collection of data for the case study: (a) include rich detail in recording events, interviews and observations; and (b) use triangulation of methods in data collection to allow crossvalidation of information.

First, we conducted a desk study of the soil fertility management literature. We also analyzed the project's archival records, such as informal reports, notes, correspondence, and so forth. Most documents concerning the project were confidential; therefore, no references are cited in this article. Data on the context - both the area and the villages in which the project carried out its activities, and participants and stakeholders - were gathered through the desk study.

Second, between October 2003 and April 2004 several visits were made to the three villages in which the project was conducted. The first author was not involved in project implementation; however, the second author actively facilitated the research and development processes associated with implementation of the project. The combination allowed both an outsider- and an insiderperspective of the project to emerge. The second author has both an agronomic and an extension studies background, while the first author is a social scientist (including anthropology), allowing for a diversity of perspectives. During the field visits, the authors made participant observations during (a) field days organized by national research and extension services, (b) participatory evaluations of the strategies proposed by farmers and organized by the international institute, (c) meetings of the regional platform, and (d) data collection by research partners in farmers' fields.

Third, the authors conducted semi-structured interviews with the stakeholders. All interviews were conducted by the authors. Approximately thirty farmers were 
interviewed individually in their fields. Three farmer groups also were visited for discussions. Three representatives of the international institute involved in the project were interviewed and joint field visits were also organized. In addition, we interviewed directors of the research, extension and agricultural policy analysis institutes that were involved in the project, as well as the professionals delegated to the project by each institute. During the interviews, the strengths, weaknesses, opportunities and constraints of project activities were analyzed. By the end of this study, all individuals involved in the project had been interviewed.

\section{Description of the project}

The Integrated Soil Fertility Management (ISFM) project, carried out between 1999 and 2003 in Central Togo, aimed to ameliorate the livelihoods of resource-poor farmers through soil fertility improvement. This focus was based on the assumption that growing crops "mines" the soil, leading to nutrient depletion, decreased soil fertility, and declining production; hence poverty (Stoorvogel and Smaling, 1990). The project focused on the adoption and maintenance of ISFM practices. The main results expected from the project were the identification and adaptation of strategies for different farming circumstances by using systematic learning with the stakeholders; making fertility management strategies, methods and data available to various stakeholders; strengthening the capacities of researchers and extension agents to successfully facilitate farmer innovation; and strengthening partnerships through project co-ordination and management.

The project facilitated negotiation among scientists, farmers, and national partners. It not only systematically tested technologies but also engaged in development activities, mainly through providing advisory services to farmers. Extension mainly offered demonstration plots, and the research was based on Participatory Technology
Development (PTD). PTD is a process of purposeful and creative interaction between farmers and outside facilitators to develop technology options. It involves processes such as gaining understanding of eco-specific and cultural contexts, defining priority problems and local experimentation, involving farmers in generating locally adapted technologies, and evaluating whether farmers internalized these technologies (Jiggins and de Zeeuw, 1992; van Veldhuizen et al., 2003).

\section{Stakeholders}

The project involved various stakeholder organizations, ranging from an international institute, decentralized departments of national extension, and research and policy analysis agencies; as well as individual resourcepoor farmers. The extension service's main activity in the project was to demonstrate innovations to stimulate diffusion of technologies to farmers through such techniques as demonstration plots, farmer field days and Individual Farm Management Advice. ${ }^{5}$ The major innovations introduced were the use of the leguminous cover crop Mucuna pririens var utilis and manure pits. Both innovations were demonstrated in farmers' fields. In addition, cereal banks were set up. ${ }^{6}$

The main research activity of the project was to set up experiments with farmers based on endogenous practices. As shown in Table 1, experiments undertaken included determination of optimal chemical fertilizers doses for a leguminous cover crop-cereal system, determination of optimal chemical fertilizer doses in a rotational leguminous cover crop-cereal system, and improvement of fertilizer efficiency in a combined leguminous cover crop-cereal system. ${ }^{7}$

Agricultural policy analysts were responsible for general coordination of the project in the Central Region and monitoring and evaluating the research processes; this included field visits for discussion with farmers and the facilitation of meetings between the

Table 1. Research activities in the soil fertility project.

\begin{tabular}{|c|c|}
\hline Village & Activity year 1 and 2 \\
\hline Ababa & $\begin{array}{l}\text { Determination of optimum rates of mineral fertilizer applications on maize in the cowpea-maize relay } \\
\text { cropping system } \\
\text { Determination of optimum rates of mineral fertilizer applications on maize in the soybean-maize rotation } \\
\text { system }\end{array}$ \\
\hline Figigi & $\begin{array}{l}\text { Improving the endogenous system of Egusi melon-maize relay cropping system through mineral fertilizer } \\
\text { applications on maize } \\
\text { Improving the endogenous system of Egusi melon-Cowpea and maize rotation system through mineral fer- } \\
\text { tilizer applications on maize }\end{array}$ \\
\hline Cedede & $\begin{array}{l}\text { Determination of optimum rates of mineral fertilizer applications on maize crops in the soybean-maize } \\
\text { rotation system } \\
\text { Determination of optimum rates of mineral fertilizer applications on sorghum crops in the cowpea-sorghum } \\
\text { mix-cropping system }\end{array}$ \\
\hline
\end{tabular}




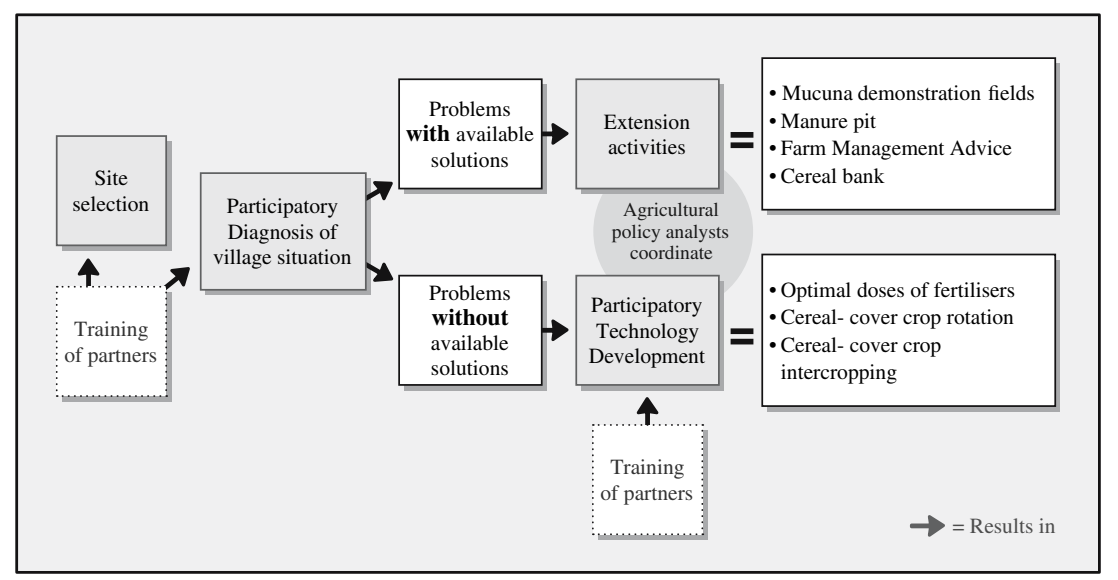

Figure 1. Sequence of activities in the soil fertility project.

different organizations (see Figure 1). The international institute supported these activities through training and monitoring.

\section{Project location}

The Project took place in the Central Region, one of five regions in Togo. This region is characterized by annual rainfall of between 1000 and $1200 \mathrm{~mm}$. There is one rainy season from April to October and harvesting takes place in November and December. Soil types include tropical ferruginous and ferralitic soils. Causes of soil degradation are sheet erosion, reduction of organic matter in the topsoil, and loss of plant nutrients (Brabant et al., 1996).

The Project had three research sites: Affem-Kabyé, Sessaro and Goubi. The three villages were selected during a workshop with the main national partners. Criteria provided by the project for site selection were accessibility (practical element); level of soil degradation, crops cultivated, and level of intensification, including fertilizers use (situational elements); and receptivity to innovation, socio-economic and cultural context, and access to innovations (social elements). ${ }^{8}$

The main cropping systems in each of the three villages were maize-based, cotton-based and yam-based, respectively. Legumes such as cowpea, soybean, groundnut and Cajanus cajan were used in rotation, and relay cropping was practiced. Although cattle were used for animal traction, the main livestock component in the agricultural system was small ruminants (sheep and goat) and poultry. The dominant ethnic group in both AffemKabyé and Sessaro was made up of Kabyé migrants from the northern part of the country. Affelees are the dominant ethnic group in the third village, Goubi. Mineral fertilizers were used, but less so in Sessaro because the village tended to have even fewer resources than the others. In Goubi, farmers tended to be less concerned about soil fertility due to the abundance of fallow land. In both Affem-Kabyé and Sessaro, compound farming was very important; but in Goubi the farms and household areas were spatially separate.

\section{Findings}

We sought to assess each of the criteria discussed in the conceptual framework using some of the proxies discussed above. Discussion of each criterion starts with a question related to the key concepts used for analysis and ends with concluding remarks.

\section{Macro-level opportunities for innovation}

Did the project take existing macro-level opportunities or potential for innovation into account? Research planning ideally is negotiated among the different stakeholders concerned, including the ultimate beneficiaries, in this case, the farmers (e.g., Johnson et al., 2003). Did this happen in practice or were project contents established at a central level?

Initial choices could have been influenced by factors such as donor requirements, the personal preferences of scientists, and the personal convictions of people involved. The quality and acceptability of these preanalytical choices (Giampietro, 2003) depended on the process through which the choices are made.

\section{Pre-analytical choices}

During the first negotiation phase between the donor and the international institute that initiated the project, several decisions were made that did not involve farmers. A first choice was that soil fertility management was to be the focus, rather than rural credit, which had initially been proposed by the international institute. The international literature (Steiner et al., 1988; Pieri, 1989; Stroosnijder, 
1992; Swift, 1996; Mazzucato and Niemeijer, 2000; Stroosnijder and Van Rheenen, 2001) suggests that soil fertility management is indeed a major issue in this region. A second decision, based on the ideas of specialized scientists within the international institute, was that agriculture needed to be intensified in order to improve production; it was assumed that an increase in production would benefit farmers and reduce poverty. A third decision was the focus on technology development rather than on rural development, which would have included development of infrastructure and markets. Such decisions can have major effects in on operationalizing project objectives.

Problems, solutions and criteria for activities that were listed during the initial donor meeting had to be grounded in the demands of country partners in order to fit the specific context. The international institute therefore organized a meeting in-country with potential stakeholders, including the governmental research and extension organizations, the agricultural policy analysis organizations, and a non governmental organization (NGO) working on credit, to present the outcomes of the donor workshop and discuss the way forward. The decision to base the Project in the Central Region of Togo was based on the need to improve the rural credit scheme, which was the initial topic proposed. This decision was not reconsidered by the partners even after the focus of the project changed. Thus, the choice of region was made before the final topic was known. It soon became clear that the NGO initially involved was not interested in the new direction that the project had taken, which in its opinion could not be linked to credit, and so decided to withdraw. Other partners, however, decided to join because of the likely importance of the subject.

\section{Concluding remarks}

The research topic, soil fertility, and general contents (problems, solutions and criteria for activities) were negotiated at a higher level of decision-making, and it respected the donor's requirements. The outcomes of the meetings with donors were discussed with local partners in the pre-selected province; however, the partners were presented with the choice to either join or withdraw, but they were not offered an opportunity negotiate the activities, objectives and conditions, since these had already been established during the donor meeting. Indeed, one prospective partner, who was not dependent on the anticipated project resources, withdrew. The other partners chose to join the project because they considered soil fertility to be a problem. No deliberate attempt was made by the international institute to understand the reasons behind partners' participation. It was assumed that the decisions made at the higher-level meetings would benefit the farmers, although they themselves were not directly consulted.
A dilemma for numerous (participatory) projects is how to involve farmers in the project planning and negotiation phase. What alternative methods for involving farmers in project development might be possible, especially in West Africa where farmers have limited political clout? In our study, it was difficult to evaluate whether soil fertility was indeed the most relevant issue to be tackled from the perspective of farmers. Despite the many justifications found in the international literature that supported the decision to focus on soil fertility improvement, it was important to verify such assumptions with farmers and to even change the topic, if necessary. Röling et al. (2004) argue that it is at least as important to provide farmers with the opportunity to influence the topic as it is to ground research in international literature. However, the fact that farmers were not involved did not mean that the topic was therefore not of interest to them. The point is that soil fertility management was chosen as the focus of the project based on donor requirements and the ideas of expert scientists, and did not take into account farmers' perspectives.

\section{Needs and expectations of resource-poor farmers}

Were the project activities grounded in the needs and expectations of resource-poor farmers? Before answering this question we need to understand who the farmers were. Only then the process used to negotiate experiments and trials can be reviewed.

\section{Types of farmers}

During a community meeting following a participatory diagnosis, farmers volunteered to participate in the project's activities. The project worked intensively with 60 households equally distributed across the three villages. Twenty-six of these households had relatively large farms (more than 5 hectares). From field observations, discussions with the farmers, and from data available within the project about farmer characteristics, it became clear that participation was predominantly from the relatively resource-rich, better-informed and well-educated male farmers in the community. A critical-minded staff member of the international institute expressed his concern. "It is worrying that only a small group of farmers is involved, and that those farmers are the ones who have relatively big fields, and much labor available."

Johnson et al. (2003) argue that farmers choosing to participate in projects are unlikely to be the poorest in the community or from a marginalized group. In addition, chances are that these farmers have had previous experience with experimentation. The agricultural extension agent also suggested that some "lead" farmers would be included. Röling (1988) stated that extension workers tend to interact with the top $10-20 \%$ of the farmers, and that in the absence of explicit efforts to involve the 
poorer farmers, it is safe to assume that the relatively better-off are involved.

\section{Gender issues}

Women were not involved in the project, despite the fact that farming at the intervention sites was largely women's work. Women sow and harvest, while men plow the land, and together they weed and maintain the plots. The neglect of gender aspects was confirmed in project documentation, which reported as early as the diagnosis phase that "a major shortcoming was the weak participation of women." The partners claimed this was due to the cultural context in which they were operating. The organization of the village was based on a hierarchical patriarchal system. Women did not generally participate in important meetings, including community and project meetings, when men were involved. As a result, only men participated in the meetings and subsequent project activities. Even when women were present at a meeting they were expected to remain quiet when in the company of men. Some women cooked food for the men attending the meetings, but this could hardly be considered participation.

The following critical incident concerning a soybean density trial demonstrates the importance of including women in experiments. A woman farmer explained that she obtained a higher yield using her traditional production method than was produced with the introduced practice. According to the researcher who was working in the area, this could be explained by the way in which the plot was sown, as follows:

When the extension agent went to the local pub to have a tchouk, he met one of the farmers participating in the trial on soybean density. Under the joy of the tchouk, the extension agent explained to the farmer exactly how to sow the plot. The farmer was to divide the plot into four quarters, sow using two different densities; two plots were to be lines and the other two at random, and apply varying fertilizer applications. Since his wife was responsible for sowing the fields, when the farmer arrived home, he immediately explained to his wife what the extension agent had just told him. A few days later the woman went to the field and sowed the plot following her husband's explanations. The woman did not fully understand the second-hand explanation and as a result there were few differences in sowing practices between the four plots. The plot did simply not respect the extension agent's protocol for research.

Because women are responsible for sowing, the project could not succeed without their involvement.

\section{Negotiating experiments}

Experiments can be based on "contracts" made between farmers and scientists. In Affem-Kabyé and Sessaro a participatory diagnosis resulted in a contract to develop collective solutions for soil fertility improvement based on local practices. In Goubi, it led to an agreement to raise awareness about the importance of maintaining soil fertility.

To ground the project in the needs, demands, and conditions of farmers, the national partners undertook a diagnostic study of soil fertility management issues with farmers using participatory methods. ${ }^{9}$ A team of agronomists and socio-economists carried out a diagnosis by visiting the villages. The study generated an understanding of community processes, as well as traditional practices and previous experiences in soil fertility management. It also allowed the partners to be properly introduced to the local authorities, and to obtain general information about the village.

The diagnosis identified concrete problems related to soil fertility decline experienced by farmers. In both Affem-Kabyé and Sessaro, the farmers believed low production to be largely the result of soil depletion. However, from the process used it cannot be concluded that soil fertility depletion was indeed a major preoccupation for farmers. Farmers may well have deduced that assistance might be forthcoming if they focused on the topic evident on the logo of the Land Rover vehicles. However, a clear indication that the farmers considered soil fertility to be a problem was their development and practice of soil fertility improvement measurements.

In Goubi, soils are still relatively fertile, and almost no chemical fertilizer was used except in cotton cultivation. The availability of unexploited land in forest areas surrounding the village allowed farmers to practice shifting cultivation. The diagnosis in this village was to take a first step, towards that of raising awareness about the threat of soil depletion in the future. The farmers indicated interest in further exploration of the situation.

Depending on the type of problems that farmers identified in relation to soil fertility, different strategies were followed. For problems that had already-existing solutions, and that were considered suitable for extension at the national level, the extension service was the main national stakeholder. A total of 114 farmers were trained in Mucuna fallowing, 30 in composting techniques, and 91 demonstration plots were prepared across the three village sites. Following information sessions on issues related to develop of cooperatives, eight farmer groups in Affem-Kabyé and two groups in Goubi started cereal banks. In addition, several field days were organized to inform non-participating farmers of these activities. The international institute also reported that 14 farmers in the three village sites received individual farm management advice. Success was measured in terms of the number of farmers reached. 


\section{Ownership of the research}

To produce innovative solutions, endogenous practices identified during the diagnosis formed a basis for improving practices through PTD. Researchers suggested a number of possible experiments based on the results of the participatory diagnosis to improve upon existing practices. The farmers in turn prioritized the options and researchers focused on about three experiments, taking into account both feasibility and farmers' preferences.

According to the international institute, the research conducted is farmer-led, on-farm research. However, ownership was not always well negotiated, and in some circumstances the experiments turned out to be researcher-led. ${ }^{10}$ Another example emphasizes the importance of ownership of the research relates to the soybean density trial in Affem-Kabyé. When discussing the trial, researchers repeatedly stressed that the experiments belonged to the farmers, who worked for themselves and not for the researchers. Some time later a farmer involved in the soybean trial explained that he decided to dig up the soybean plants that had not received fertilizers because they were not doing well. As a result the difference in yields was not large. One of the researchers got mad at the farmer and asked him why he had not done what he was told to do. The researcher then explained to the farmer that the results were no longer comparable due to his intervention and had become useless. A bit later the researcher calmed down and requested that the farmer would not act in such a way again. The farmer replied, "Yes sir, I will not deceive you again, and I will not spoil your experiment again."

During the first two cropping seasons no control plots were set up because farmers did not see the benefits. As such it was impossible for biological scientists to make sound statements. During the third cropping season, the trial design was therefore renegotiated and control plots were included in order to make the study scientifically sound according to the criteria of biological science. The researchers managed to convince the farmers that they needed a control plot in order to be able to draw conclusions. In one of the villages it was very difficult to convince the farmers of this need. Farmers in Affem-Kabyé argued that they always used fertilizer in maize production; therefore, they did not think it sensible to compare a fertilized plot to a plot where no fertilizer had been applied (i.e., the control). In another case, a farmer in Goubi applied fertilizer to a control plot because he was not willing to risk production losses.

At times, it appeared illogical to farmers to compare an introduced practice with what they already did. The experience of Björnsen Gurung (2003) confirmed that the scientific approach of comparing two systems that differed by only one factor was indeed illogical for farmers. Because farmers seek benefit rather than proof, it is incomprehensible for them to leave parts of their plots untreated when there is another production method that is more likely to succeed (ibid).

During the first two cropping seasons, different trials were conducted in the three villages depending on farmer preferences. However, biological scientists required that treatments be replicated so that they could say something about the effect of an introduced practice (because of possible side effects). It was therefore necessary to conduct the same trials in all three villages for several cropping seasons. This design allowed biological scientists to gather sufficient data. As such, farmers' needs were given less priority during the third year and the conditions for the experiments proved to have been insufficiently negotiated. The farmer in Goubi who hosted the soybean varietals trial explained that other farmers rarely came to see the experiment. He explained this by repeating what he had already indicated during the diagnosis phase, that local farmers do not have a soil fertility problem. Hence farmers participated by providing their fields and labor to carry out experiments for scientists on a topic in which they had already indicated disinterest during the diagnostic phase.

\section{Concluding remarks}

Ideally, the diagnostic phase provides ample opportunity for negotiating between farmers and researchers so that the interests of both are met. However, the international institutes made several pre-analytical decisions about project design that farmers and partners could not influence but instead were compelled to accept. First, it was assumed that (a) solutions for some problems were already available and could be brought to farmers via extension services and (b) some solutions were not yet available and demanded exploration with farmers. Secondly, "productivity" was chosen as the criterion for success. This favored a focus on large farmers for whom uptake and impact generally happen more quickly. What the participatory diagnosis did not address was the context within which the project strategies were embedded, such as market outlets, availability of fertilizers and seed, different soil fertility management approaches by landowners and migrants (Adjei-Nsiah et al., 2004; Saïdou et al., 2004).

After the donor withdrew and the ISFM project was integrated into another project of the same international institute, the role of biological scientists became increasingly more important. As a result, the requirement to produce scientifically sound data prevailed. Scientific rigor made it necessary to compare two systems that differed by one factor and were replicable. Experimental science requirements - such as the ability to replicate and the need for controls in order to draw scientifically sound 
conclusions - were not sufficiently negotiated with farmers.

So, why did the farmers agree to the proposed experiments? One group of farmers answered this question with respect to their readiness to participate in the research trials thus, "If you give us the inputs we want to participate, but if we have to buy them ourselves that changes everything!"

\section{Benefits for resource poor farmers}

It is important to ask whether the project designed systems that worked under farmers' conditions and were acceptable and appropriate for resource-poor farmers. The project delivered extension messages about problems for which solutions were considered available and engaged in further trials with farmers on other issues. Have these two types of efforts benefited resource-poor farmers? Did the context allow the innovations introduced to benefit resource-poor farmers? Below, the perspective of each of the stakeholders is discussed.

Evaluation of project results by the international institute Based on an evaluation of the project's research activities, ${ }^{11}$ the international institute concluded that the systems developed were effective in the farming system under study. The most successful participatory trial was the relay cowpea-maize cropping system. The yields in this system were comparable to the optimal yields obtained in a simulation model. Average maize grain yields doubled in two years. The farmer who had the highest level of production - seven tons per ha - was based in Affem-Kabyé. The trial in which he was involved allowed farmers to harvest two different crops on the same plot in a single cropping season. The average maize grain yields in the Egusi melon-maize relay cropping system also increased, but not impressively. The use of fertilizers in the endogenous Egusi melonCowpea and maize rotation system improved maize grain yields. The effect of both fertilizers and a preceding cowpea crop improved yields. Also, the yields were higher where the residues of soybean were incorporated into the soil in a soybean-maize rotation system, although the difference was not large. Another result was that an improved sorghum variety was found not suitable for the cowpea-sorghum mixed cropping system. The main criterion for the international institute was yield; hence, the results of the PTD activities seemed promising. However, how many farmers can achieve these results? And if they can, is there a viable strategy to market the surplus production?

\section{Evaluation of project results by national partners}

Both researchers and extension workers expressed their satisfaction with the project's results. They most appre- ciated the project's participatory approach. Researchers and extension workers felt that farmer knowledge was taken seriously and that farmers were involved in the experiments. However, researchers and extension workers seemed reluctant to openly criticize the project. An initial explanation for their reticence might be that the project provided researchers and extension workers with supplementary revenue (in the form of a daily subsistence allowance for field trips and remuneration in the case of extension workers) and as a result they had an interest in sustaining it. A second explanation might be that researchers did not think criticism would make a difference. Researchers themselves have become skeptical about the impact a project can have on sustainable development. Indeed, some researchers have lost confidence in what can be achieved through a research project. ${ }^{12}$

From the interviews it appeared that agricultural policy analysts appreciated the project results very much because they felt the results contributed to the development of options for increased production. Increased yields also improved the analysts' credibility vis-à-vis the farmers. Due to increased production, (urban) consumers could purchase produce at a lower price. In an informal discussion, the director of the agricultural policy institute courageously admitted that farmers then would receive lower prices. So, farmers do not share the same interests as (urban) consumers and alternative marketing options for farmers must be found. A major drawback of the project, according to the director, was the limited funds available; consequently, there were limited possibilities for scaling up to other districts. Understandably, researchers and extension workers supported this view.

\section{Evaluation of project results by farmers}

The soil fertility improvement technologies tested were often positively evaluated by farmers and project partners alike. These evaluations focused on the technical performance of the innovation under specific conditions; however, the technical performance of an innovation is just one reason for adoption. The critical incidents reported in Table 2 demonstrate the mix of criteria used by farmers.

Table 2. Farmers' indicators for assessing an innovation.

\begin{tabular}{ll}
\hline $\begin{array}{l}\text { Indictors in the } \\
\text { technical domain }\end{array}$ & $\begin{array}{l}\text { Indicators in the } \\
\text { socio-economical domain }\end{array}$ \\
\hline Yields & $\begin{array}{l}\text { Land tenure arrangements } \\
\text { Organic biomass content }\end{array}$ \\
$\begin{array}{l}\text { Integration in farm } \\
\text { (Multi-purpose crop) }\end{array}$ \\
$\begin{array}{l}\text { Farming calendar } \\
\text { Marketing possibilities } \\
\text { Cost efficiency } \\
\text { (investment needed) } \\
\text { Short-term benefit } \\
\text { Labor needs }\end{array}$ \\
\hline
\end{tabular}


Results from extension messages

An important technology introduced by extension was the use of Mucuna puriens as a green manure cover crop to increase soil organic matter content. It was observed, however, during the farm visits that few farmers used Mucuna. In general the farmers at the research site acknowledged the effect of Mucuna to be remarkable due to its capacity to increase biomass, hence organic matter content. Yields of maize increased considerably if Mucuna had preceded it. It was reported by scientists involved in the project that one year of Mucuna production could be equated with five years of fallow. However, the use of Mucuna for improved soil fertility had major drawbacks, according to the farmers interviewed such as (a) slow decomposition of stalks in the field; (b) inflammability of the dry Mucuna crop; (c) the likelihood of tenants losing their plots because owners withdraw them from the tenant's use after a Mucuna season; high labor requirements; and (d) the fact that Mucuna cannot be used for other purposes such as seed consumption, animal fodder or building material. Also, this part of the country has only one rainy season, so that farmers reported that they would "lose the season" if they cultivated Mucuna. One farmer explained, "If the rains come you have to choose your crops, and since we cannot eat Mucuna, the choice is quickly made." Other technical problems included that Mucuna is difficult to plough under with animal traction; it provided favorable environments for scorpions and snakes; it germinated abundantly the year after sowing due to bursting of pods, and it needed to be protected from bush fires. The farmers explained their low uptake of Mucuna through reasons other than technical performance and yield increases. Deffo et al. (2002, 2004), Tarawali et al. (1999), and Manyong et al. (1996) reported similar problems with Mucuna. Several farmers explained that they had already tried Mucuna before the project came to their village and that they planned to abandon it once the project ended. The Mucuna story shows that available technology that is "on the shelf" according to scientists is not necessarily acceptable to farmers. Figure 2 provides an overview of farmer reasons influencing Mucuna uptake.

Extension activities also triggered individual discovery learning, demonstrated in this account of a critical incident.

Some of the farmers who did not want to lose an entire cropping season to Mucuna tried intercropping Mucuna with maize. Others preferred intercropping sorghum with Mucuna because of the cultural and social value attributed to sorghum. Despite the project's warnings that Mucuna would overrun the sorghum, one farmer in Sessaro decided to try this practice in his field. In fact, he had already concluded that his sorghum production yield was lost and therefore could afford using that plot for experimentation. During a field day a group of farmers visited his plot and concluded that Mucuna had indeed largely overrun sorghum. Although scientists concluded the practice was not successful, one farmer commented, "Even though I agree that Mucuna

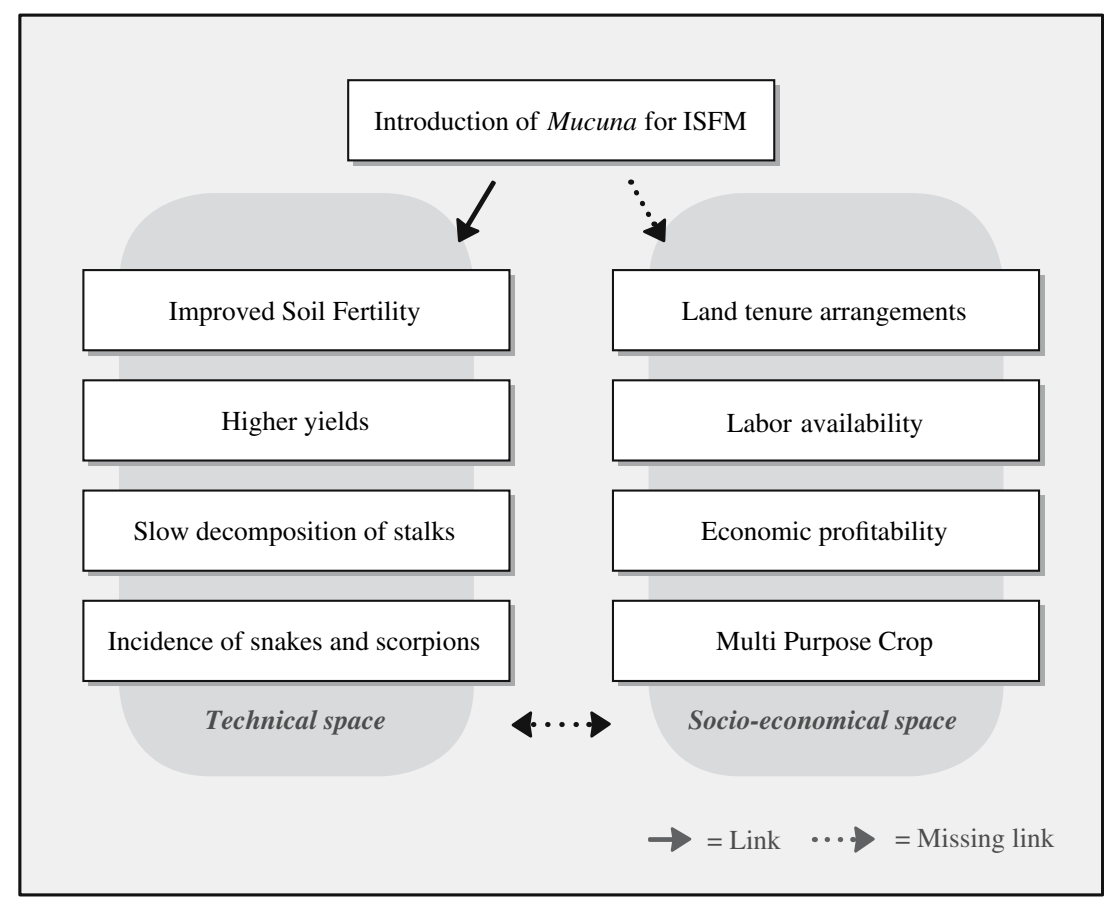

Figure 2. Linking technical and socio-economical space: the case of Mucuna. 
overruns sorghum, the farmer improved his soil fertility and in addition he has at least some sorghum which is already better than Mucuna alone!"

The example demonstrates that stakeholders use different indicators to measure an innovation's success.

The project aimed to improve soil fertility through ISFM strategies such as organic manure, chemical fertilizers and cover crops. As a result of these practices, the production of maize, for example, increase as reported earlier. During our field visits, the major preoccupation of farmers was the slump in maize prices. Even though farmers had a surplus of maize, it was not possible for them to actually sell it. One farmer said, "We followed your advice to improve our soil fertility, and now here we are with our surplus. What are we supposed to do with our maize? You should not advise people to produce more if you have no market for the produce."

Consequently, the Project introduced cereal banks. Cereal banks allow storage of produce immediately after harvest when the price is low, to be held until the price goes up again. However, this final year, farmers complained that the price remained low year-round. ${ }^{13}$ After analyzing the statistical data from FAOSTAT, ${ }^{14}$ it was indeed confirmed that the price decreased by $25 \%$ compared to the previous year and $20 \%$ compared to the five-year average. The fact that production had only increased slightly (i.e., $1 \%$ compared to last year and $12 \%$ compared to the five year average) was an indication that more maize was available on the market. The reason was likely due to the fact that maize production in neighboring countries increased by $21 \%$ compared with the previous year. Also, cheap maize and other food product imports year-round have undermined the seasonal rhythm on which the cereal bank was based.

Fertilizers are generally expensive, ${ }^{15}$ if available at all, and as a result production costs are high. In such a situation, fertilizer application may increase yields, but higher yields may not improve resource-poor farmers' livelihoods, if not accompanied by institutional or socioeconomic development. One farmer stated, "We do not need your help anymore to increase our production levels, because we attained that objective and know how to do that, but we want you to change your objective and help us with better markets for our yields."

The introduction of cereal banks did not prove to be sufficient to overcome the marketing problem. Figure 3

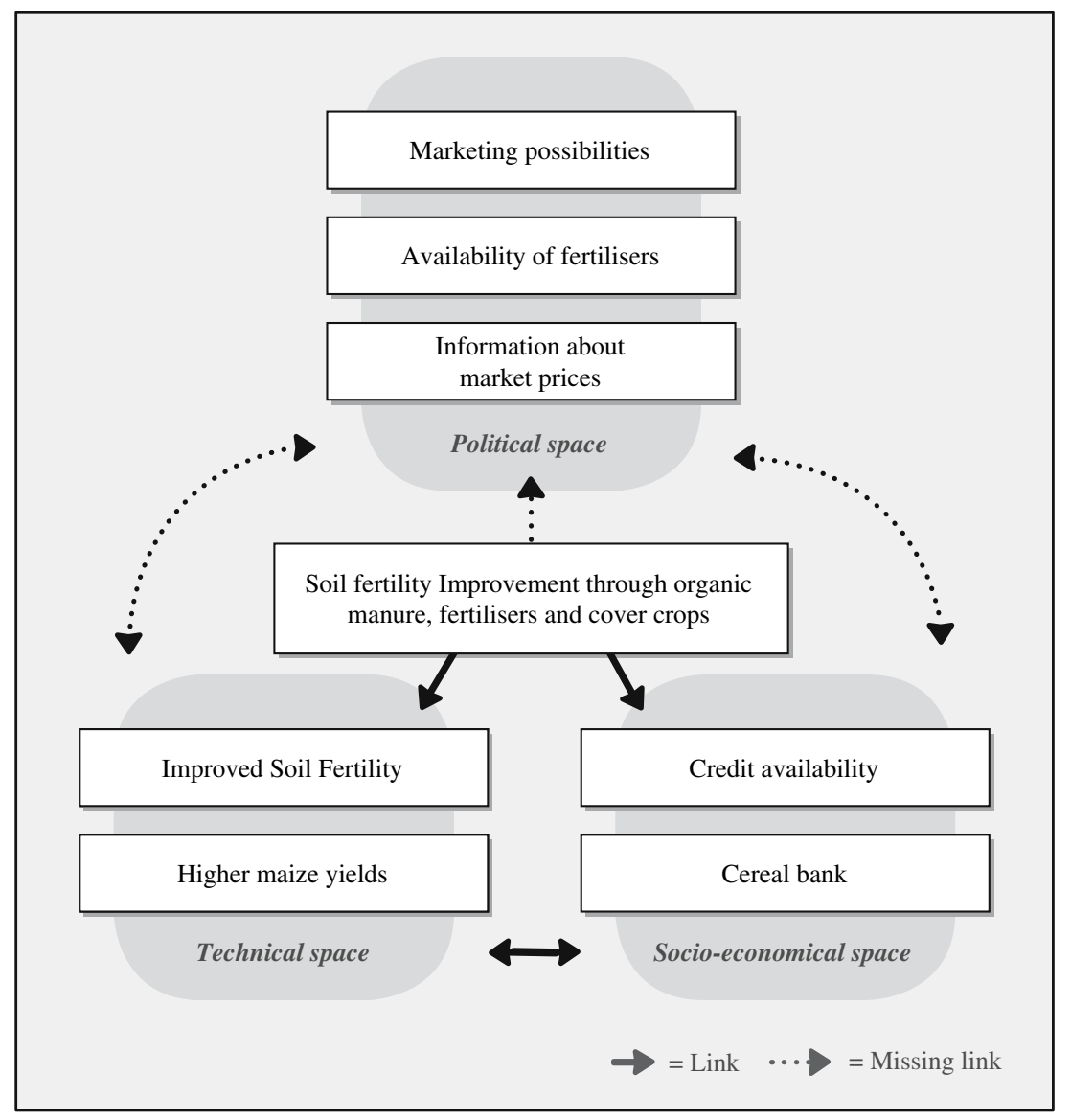

Figure 3. Linking socio-economical, technical and political space. 
gives a schematic overview of how different factors are interlinked. One of the staff members of the international institute argued "The Project should not take increased productivity out of its context, but look at the entire context prerequisite for rural development that is networking, knowledge and information, market development and credit."

Giller et al. (2003) discuss the different impacts that policy can have (see Figure 4). In a discussion with a group of farmers and the agricultural extension agent in Sessaro about individual farm management advice, the following concern was raised:

The farmer you see over there does not want other farmers to visit his field during the farmer field day this year. During last year's farmer field day he got a lot of attention when visiting farmers were impressed by the high yields he was able to produce due to the soil fertility improvement strategies he had practiced. Shortly after the farmer field day he fell ill. The farmer claims that one of the visiting farmers has bewitched him out of jealousy about the high yield he obtained. He dropped all the practices the individual farm management advisor had recommended even though he was convinced of their benefit. The farmer spent all his money on medicines and has ,no force' left to work in the field. The farmer argues that it does not make sense to become rich if it means losing your health or maybe even your life.
This example demonstrates that the often-made assumption that individuals can progress if they make an effort can be wrong in another social context. Leveling mechanisms that aim to "even out" the distribution of wealth (Nanda, 1990) are very strong and imply that people do not want to publicly display their wealth (Breusers et al., 1998). Farmers believe witchcraft to be real in its consequences and capable of having an impact on their well-being. Leveling mechanisms can take many forms (Nanda, 1990) and in this case resulted in a lack of follow-up on project recommendations.

\section{Results of research experiments}

Experiments on soybean to increase organic matter content were conducted. Soybean is a non-traditional crop and is not often consumed in the rural communities involved in the study. ${ }^{16}$ An NGO contracted farmers to produce soybean and guaranteed a ready market for the produce. The presence of a market outlet motivated farmers to engage in soybean production. Moreover, they preferred soybean to Mucuna. The advantage of soybean is that it is a multi-purpose crop (food, fodder, organic matter). In addition, soybean had market potential. Farmers were however primarily interested in soybean grains and considered the soil fertility improvement effect as an advantageous side-effect, whereas soil scientists mainly evaluated soybean on the basis of the biomass available for soil fertility improvement. A farmer

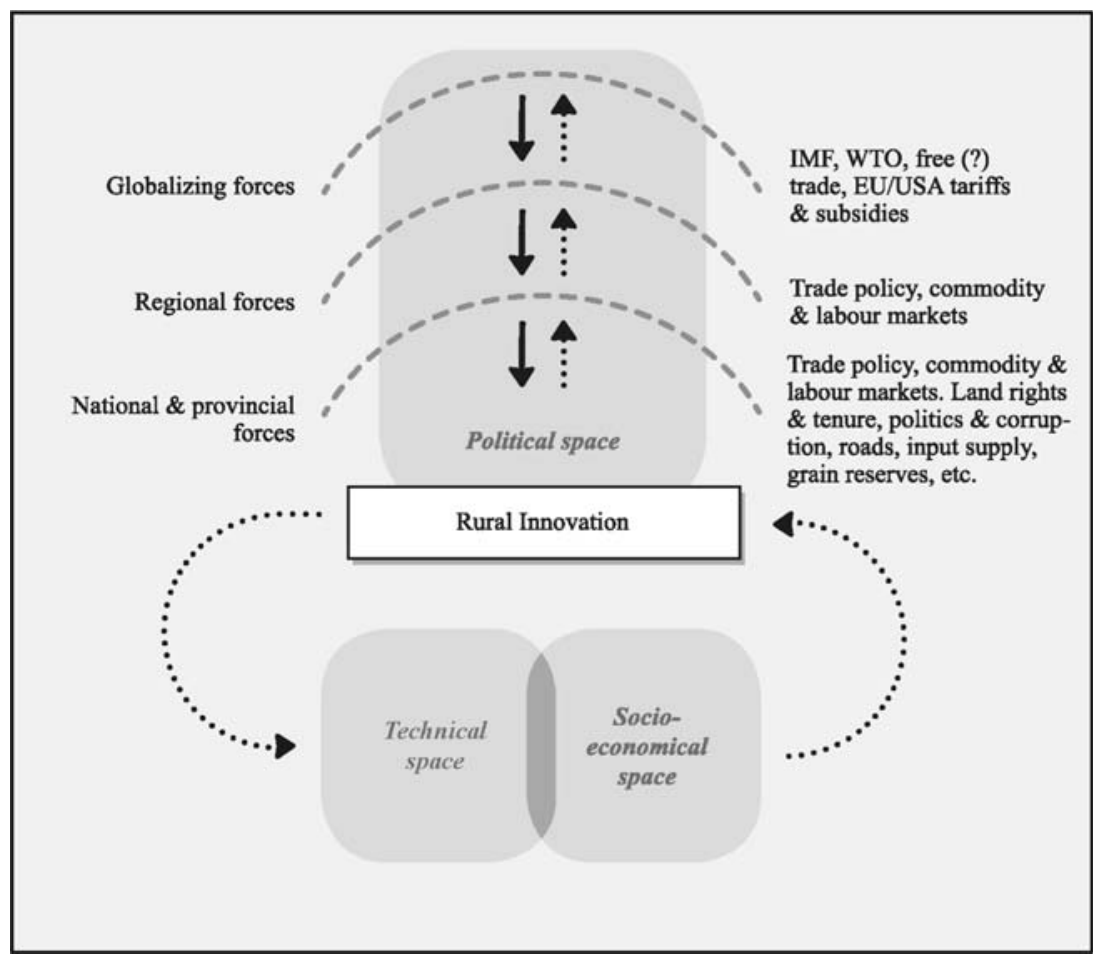

Figure 4. Political space further explored (adapted from Giller et al., 2003). 
commenting on the soybean varietals trial observed, "The soybean variety soil scientists prefer is indeed high and green but that is not what we look for. The variety they choose has only two grains per pod and the pods are only near the top, not covering the whole stalk."

One farmer who participated in a soybean trial had left the residues in the field for distribution over the land the next day. In the evening his brother passed by and noticed the heap of soybean residues. He decided to clean the plot for his brother and burned it. This illustrates that it is not only the owner who makes decisions about the plot, but also other family members.

Farmers prefer cowpea, on which experiments were also conducted. Cowpea can be planted very early and rotated with maize during the same cropping season. Cowpea does not only have a positive effect on maize yields but, more importantly, can be used to bridge the hunger gap (it can be harvested very early) and can also be sold on the local market. In addition, cowpea is a multi-purpose crop that fits more easily into the farming calendar due to its early harvest. The problem with cowpea is its susceptibility to pests. However, for the year we reported on, very few farmers planted a cowpeamaize rotation trial because the rains came too late, leading the farmers to decide that it was impossible to sow cowpea before maize. In this example, climatic conditions led farmers to decide that the trial would not be interesting. This illustrates, once again, that technical solutions are not fixed blueprints but depend on a complex mix of factors.

A farmer participating in the relay cropping EgusiMaize on-farm trial in Goubi did not respect the fertilizer rate application stipulated in the protocol. He bought additional fertilizer, which he applied both to the treatment plot and to the control plots. Maize yields on the different treatments plots motivated the researchers to investigate the situation. The farmer explained that he wanted high yields on his plots and applied what he had learned in the previous year from the project's activities.

\section{Concluding remarks}

Scientists in the project focused on designing systems that were effective and focused less on "appropriate technologies," The experiences with Mucuna probably provided the clearest example. The high yields obtained with Mucuna convinced scientists that farmers would accept the crop, overlooking the fact that farmers used additional criteria to determine acceptability. Therefore it is necessary to consider farmers' conditions for acceptability. Another example was the early indication from farmers from Goubi during the diagnostic phase that soil fertility degradation was not a problem. Even when soil fertility is an issue, farmers may not use fertilizers if they are either unavailable or considered to be too expensive. The case study demonstrates that farmers had veto power
(Röling et al., 2004) and will not use technologies that do not benefit them. Scientists determined what was (or was not) a solution for the farmers, but did not take into account that farmers may have had other priorities and that increased production was not necessarily amongst them, depending on other conditions. Whereas the soil scientists involved in the project used yields and biomass content as the main indicators of success, farmers used a mix of criteria both in technical and socio-economic domains in which yield was only one factor, albeit an important one.

The farmers selected for participation in the project were predominantly the relatively resource-rich farmers in the community due to increased chances that such farmers would adopt the strategies introduced. These farmers complained that their main problem was the commercialization of their produce. It could well be that the project targeted the wrong farmers. ${ }^{17}$

The farmers we spoke to complained about the lack of market and low prices. This also demonstrates that new problems arise as a result of solving old ones. Therefore a continual assessment of the context is required if the aim is to design research that is useful for resource-poor farmers.

\section{Innovations that can be scaled up}

"Scaling up" usually means moving beyond the local or pilot level to include more beneficiaries and to involve other agencies in terms of management and funding, with a view to making a larger impact that is beyond the original project's duration (while continuing to foster participation of intended beneficiaries and other stakeholders involved) (Uvin and Millar, 1994; Douthwaite et al., 2003). What lessons can be learned about what the Project has done to scale up its pilot activities?

\section{Intra-institutional collaboration}

A platform was constituted to involve different institutional actors and thereby influence the political scene for scaling-up purposes. A Project Co-ordination Committee (PCC) was established to facilitate the implementation of the project, guide the research process, and make it possible to continue activities in the project area. It was hoped that this PCC would eventually carry out the activities by itself. A platform perspective was used (Dangbégnon et al., 2001) to set up such a collaborative development and research framework. The PCC consisted of the national partners in research, extension, and agricultural policy analysis; and the international organization. As such, the PPC helped to inform and involve policy makers at the level of the Central Region of Togo. Farmers and their organizations were not represented. The PCC was designed as an inter-institutional platform and functioned as a forum for negotiation between the national stakeholders (see Figure 5). ${ }^{18}$ 


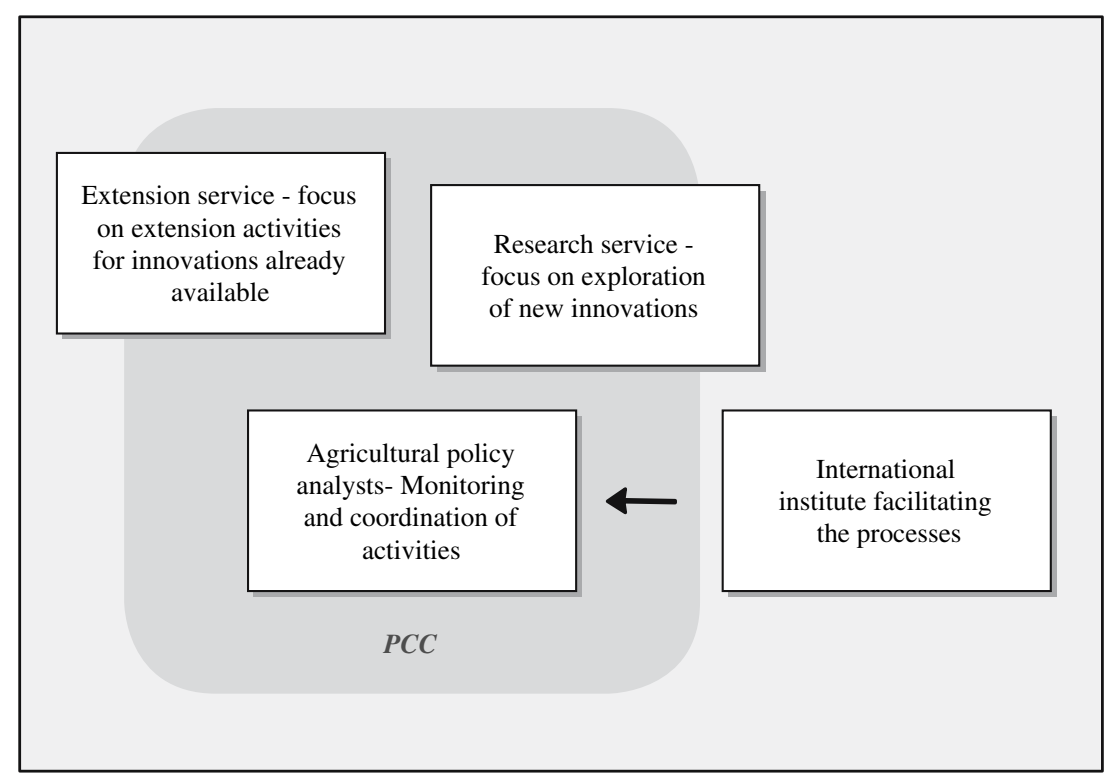

Figure 5. An inter-institutional platform in the Soil Fertility Project.

A difficulty encountered by the project was the high turnover of the PCC members; in the end, none of the original members remained involved. The new members had to be briefed about the history, norms and rules of the platform. Another problem was the lack of communication between the people on the platform and the members of the organization they represented. Collective commitment to continuation of the platform and the project activities was not evident.

\section{Spontaneous scaling up}

"Informal" or "spontaneous" horizontal scaling up through diffusion had taken place. Such a process is also referred to in the literature as "scaling out" (Douthwaite et al., 2003). Several farmers from surrounding villages or non-participating farmers from the same village reported, for example, having received seed from fellow farmers or having heard about the project from a neighbor. These farmers also experimented before adopting the practices demonstrated. In addition, during the farmer field day, it was observed that farmers from other villages who had not received invitations also participated. There had been no incentive such as transport reimbursement. A critical staff member of the international institute wondered whether they should continue to invest in trials, given that farmers are capable of experimenting independently.

\section{Other dimensions of scaling up}

Scaling up has, however, another dimension. The case study clearly showed that technical aspects (e.g., soil fertility, productivity per ha) were but one bottleneck in development. Once they were overcome, other issues such as marketing become the limiting factor. Spontaneous diffusion of technical innovations, the great multiplier of research impact (e.g., Rogers, 1995), requires a favorable context. This includes availability of and access to credit facilities, security of land use, timely access to high quality fertilizers, appropriate and functioning extension services, and most importantly the availability of and access to marketing channels and acceptable prices.

\section{Concluding remarks}

For scaling up, the notion of replicability is essential. One cannot expect the project process to be replicated if the conditions created by the project were artificial. Several factors impact on scaling up. In the first place, partnerships that allow for interaction and ownership among different stakeholders need to be built so as to foster internalization of the project objectives. Secondly, the political context must be favorable. Finally, scaling out requires that diversity in the farmer population be taken into account. Resource-poor farmers do not necessarily have the same options as large farmers. When women do the farm work, it is important that they be included.

\section{Emerging lessons}

The case study analysis, based on five criteria for farmeroriented research, allowed us to draw a number of lessons regarding agricultural research that is effective in ameliorating the livelihoods of resource-poor farmers. During fieldwork, farmers mentioned on several occasions that the research conducted does not always 
address their needs and that research results do not routinely benefit them. What explains the (lack of) impact of the ISFM Project on farmers' livelihoods? By way of conclusion we assert the following.

\section{Pre-analytical choices determined the scope and possible impact}

Pre-analytical choices were made by donors and the international research institute but were insufficiently negotiated with resource-poor farmers. The project was not used to develop effective farmer clout over the project's activities. Consequently, ownership of the activities remained with the scientists and planners, with the result that the technologies introduced and tested did not adhere to the criteria outlined at the beginning of the article and will not autonomously diffuse amongst farmers.

Solutions that are technically sound are not necessarily acceptable to resource-poor farmers

The assumption that science has technologies on the shelf that can solve farmer problems is particularly dangerous. In this case study, scientists decided that existing technologies (for example the use of Mucuna to increase organic matter content) provided the best technical means to solve soil fertility problems. This decision was based on a test of "what worked" and not "what was acceptable." However, scientists decided what works on the basis of narrow criteria e.g., Mucuna's contribution to organic matter content and yield. Farmers used a more complex set of criteria such as labor costs, production of edible grains, and so forth.

\section{Solving a problem generated other problems}

When some farmers improved soil fertility and increased production, they could not market their produce. This means that agricultural research must continually engage in diagnosis of the relevant problems. Also, the context changes (e.g., prices for agricultural products rise and fall), affecting the relevance of project activities.

\section{Appropriate categories of farmers need to be addressed}

Farmers are not homogenous in terms of needs and perceptions e.g., soil fertility is an urgent problem for resource-poor farmers who do not have the labor or the financial means available to improve soil fertility, hence have limited "space for innovation." However, the project seemed to focus on farmers with the means and labor to deal with soil fertility problems, but who instead faced market challenges (for their surplus production). In addition, other procedures to involve women need to be explored.

The farmers revealed that a complex mix of socio-economic, political and technical factors influenced uptake or rejection

Farmer uptake can only be understood if the socio-cultural context is taken into account. Cultural values are too often overlooked, yet have a major impact on how resource-poor farmers perceive agriculture and the usefulness of the technologies proposed.

\section{Summary}

Many questions remain unanswered when it comes to the critical issue of making agricultural research relevant to achieving the Millennium Development Goals. But our case study demonstrates that it is not enough to develop systems that work. Farm innovation needs to be embedded in macro-level opportunities, grounded in resource-poor farmers' needs, be acceptable to them, and allow for scaling up.

\section{Acknowledgements}

We would like to acknowledge the different stakeholders and farmers who dedicated their precious time in order to do interviews with us. We would also like to acknowledge the International Institute for allowing us to look critically at its work and access confidential documents. It is because of this open attitude that we managed to learn so much. We are pleased to know that an earlier draft of our work also led to constructive discussion within the Institute. The first author was employed by the Food and Agriculture Organization (FAO) through the Dutch Ministry for Development Cooperation (DGIS) at the time the study was carried out and she gratefully acknowledges this support. We acknowledge the constructive comments of Niels Röling, Arnold van Huis, Aubert Ouango, Thom Kuyper and Ken Giller on earlier drafts. The views expressed are nevertheless our own.

\section{Notes}

1. Convergence of Sciences $(\mathrm{CoS})$ is a research program (2002-2006) that has been executed by a consortium of the Université de d'Abomey-Calavi, Benin; the University of Legon, Ghana; and Wageningen University in the Netherlands. Within the program eight African students worked with a group of farmers who developed technologies in such areas as land use and soil fertility, weed management and plant genetic 
diversity for food crops, and integrated pest management. They also experimented with ways of improving the framework conditions for technological innovation (Röling et al., 2004; Hounkonnou et al., 2006; A. van Huis et al., submitted). The first author was conducting $\mathrm{PhD}$ research within the frame of the $\mathrm{CoS}$ program to draw comparative lessons from the eight farmer-scientist interactions, in order to throw light on research procedures, methodologies, and processes that were assessed for their effectiveness in improving the livelihoods of resource-poor farmers. The approach $\mathrm{CoS}$ used is based on a convergence between scientists and farmer and between biological and social scientists and comprises different phases (see also E. S. Nederlof et al., submitted).

2. For purposes of confidentiality the name of the project has been changed.

3. Röling used insights from Van Schoubroeck (1999) and Tekelenburg (2001).

4. People participate in a joint analysis that might lead to action planning and the formation or strengthening of local institutions. It tends to involve interdisciplinary methodologies that seek multiple perspectives and make use of systematic and structured learning processes.

5. Individual Farm Management Advice is better known under its French name: Conseil de Gestion. It is a holistic extension tool for an individual household and aims to improve production levels and soil fertility strategies. It consists of a series of visits by the extension agent to the farmer aimed at giving her or him farm-specific advice. Results are encouraging but the scope for scaling up is limited due to the high costs involved and the low farmer-extension worker ratio.

6. A cereal bank (Kpaikpai, 2003) consists of a group of people who agree to jointly store their products when prices are low and the product is abundant. When the product becomes scarce and prices increase, the product is sold. This not only allows selling the product at a higher price, but since prices are in general higher just before the next season starts, it also makes cash available at a time it is needed for the start of the next season (e.g., for purchasing agricultural inputs, hiring labor). Well-known drawbacks of cereal banks are that the moisture content of the grains, and as a result the weight, decreases; individuals might want to sell the bags at other times; costs for a care taker; and other additional costs that are not foreseen by farmers and may result in accusation of stealing (Röling, pers. comm.).

7. These experiments were based on contracts that were made between farmers and scientists during the diagnosis.

8. Given the institutional complexity of the Project, the selection could have been influenced by any of a number of factors, including personal reasons of officials.

9. Tools used were community mapping, transect walk, semi-structured interviewing, flow diagram, wealth ranking and Venn diagramming.

10. When the agricultural extension agent was harvesting the soybean density plot together with the farmer on whose land the trial had been installed, the farmer became tired and left. He told the agricultural extension agent he would take a rest and return but he never came back and left the agricultural extension agent alone with the work. This was the farmer's way of saying he did not agree with the manner in which they had to harvest the field for the scientists. The agricultural extension agent followed the evaluation form handed out by the research service, which included an indicator on the number of grains. To estimate the number of grains, the soybean had to be threshed, what usually is not done. The farmer did not understand the logic of doing this additional work and decided to withdraw. It later appeared that the agricultural extension agent indeed misunderstood the requirement. The case shows that farmers not only negotiate through discussion but also through action. In this example indicators for evaluating the trial were not negotiated, and as a result the experiment turned out the agricultural extension agent's responsibility rather than the farmer's.

11. Plots of similar size and different applications were harvested and yields put in a bag. The bags were compared to determine best practices.

12. During a field trip to discuss some preliminary findings of the project activities of the preceding season with the farmers, a young researcher was discouraged by the low uptake of some of the strategies proposed. The discouragement was very evident from the expression on his face. When the other researchers returned to the car, we overheard them commenting on the young researcher. One of them said: "poor guy, he still believes farmers will one day adopt what researchers introduce", and another added: "once he has more experience he will learn that making a change for farmers is no more than a dream". The researchers continued commenting on the young researcher stressing that no research project they have ever seen has made an impact.

13. The problem of maize price slump seemed to be a regional one. Farmers had the same complaints in the Central region of Benin (observation in S. Aliou's field on 17.10.03) and in Burkina Faso.

14. FAOSTAT data available online at http://faostat.fao.org/site/340/default.aspx

15. The cost is the equivalent of 15.5 US dollars, 
e.g., 7500 FCFA for a bag of 50 kilos. See http:// www.oanda.com/convert/fxhistory.

16. At them time of writing, however an NGO demonstrated how soybean cheese and mustard can be produced and soybean is gaining popularity for home consumption.

17. Thom Kuyper (personal communication).

18. The concept of "platform" originally emerged in the context of natural resource management (Röling and Jiggins, 1998). Currently it has, however, a much wider applicability.

\section{References}

Adjei-Nsiah, S., C. Leeuwis, K. E. Giller, O. Sakyi-Dawson, J. Cobbina, T. W. Kuyper, M. Abekoe, and W. van der Werf (2004). "Land tenure and differential soil fertility management practices among native and migrant farmers in Wenchi, Ghana: Implications for interdisciplinary action research." NJAS Wageningen Journal of Life Sciences 52: 331-348.

Ashby, J. A., A. R. Braun, T. Gracia, M. P. Guerrero, L. A. Hernández, C. A. Quirós, and J. I. Roa (2000). Investing in Farmers as Researchers: Experience with Local Agricultural Research Committees in Latin America. Colombia: Centro Internacional de Agricultura Tropical (CIAT). Retrieved from http://www.ciat.cgiar.org/downloads/pdf/Investing_farmers.pdf on 2 August 2006.

Bie, S. W. (2001). "The 1990s: An important decade for agricultural research in developing countries." In International Service for National Agricultural Research. Annual Report 2000: Reflecting on an Important Decade for Agricultural Research in Developing Countries. The Hague: International Service for National Agricultural Research.

Björnsen Gurung, A. (2003). "Experiments in store: Participatory Action Research with women farmers of Nepal." Beraterinnen News. Lindau, Switzerland: Landwitrschaftliche Beratungszentrale 1: 31-38.

Brabant, P., D. Darracq, K. Egué, and V. Simonneaux (1996). Togo: Etat de Dégradation des Terres Tésultant des Activités Humaines. Paris: Editions de l'ORSTOMCollection Notice Explicative No. 112.

Breusers, M., E. S. Nederlof, and T. van Rheenen (1998). "Conflict or symbiosis? Disentangling farmer-herdsmen relations: The Mossi and Fulbe of the Central Plateau, Burkina Faso." Journal of Modern African Studies 36(3): 357-380.

Castillo, G. T. (1998). “A social harvest reaped from a promise of springtime: user-responsive, participatory agricultural research in Asia." In N. Röling and M. Wagemakers (eds.), Facilitating Sustainable Agriculture: Participatory Learning and Adaptive Management in Times of Environmental Uncertainty, (pp. 191-214). Cambridge, United Kingdom: Cambridge University Press.

Chambers, R. (1990). Développement Rural: La Pauvrete Cachée. Paris: Editions Karthala and Wageningen, The Netherlands: CTA.
Chambers, R. (1994). "Participatory Rural Appraisal (PRA): Analysis of experience." World Development 22(9): 12531268.

Chambers, R. (1997). Whose reality counts? Putting the last first. London: Intermediate Technology Publications.

Chambers, R. and J. Jiggins (1987a). "Agricultural research for resource-poor farmers. Part I: Transfer-of-Technology and Farming Systems Research." Agricultural Administration and Extension 27: 35-52.

Chambers, R. and J. Jiggins (1987b). "Agricultural research for resource-poor farmers: A parsimonious paradigm." Agricultural Administration and Extension 27: 109-128.

CIP (International Potato Center) (2003). Farmer Field Schools: From IPM to Platforms for Learning and Empowerment: Users' Perspectives with Agricultural Research and Development. Los Baños, Laguna, Philippines: International Potato Center.

Collinson, M. P. (ed.) (2000). A history of Farming Systems Research. New York, New York: CABI Publishing and Rome, Italy: Food and Agriculture Organization,.

Dangbégnon, C., A. Blum, E. S. Nederlof, N. Röling, and R. C. Tossou (2001). Platforms for Sustainable Natural Resource Management: The Case of West Africa. Amsterdam: NIRP, KITResearch for Policy Series No. 10.

Deffo, V., S. Hounzangbe-Adote, R. Maliki, M.E.H. Ould Ferroukh, and E. Torquebiau (2004). "Contraintes contingentes à l'adoption d'une technologie. Evaluation contingente des contraintes à la fertilisation des sols par le système maïs-mucuna-engrais minéraux au Sud Togo." Tropicultura 22(1): 19-25.

Deffo, V., S. Hounzangbe-Adote, R. Maliki, M. E. H. Ould Ferroukh, E. Torquebiau, and H Van Reuler (2002). "Options d'intensification durable des cultures vivrières au Sud du Togo." African Crop Science Journal 10(3): 239-249.

Denzin, N. K. and Y. S. Lincoln (eds.). (1994). Handbook of qualitative research. Thousand Oaks, California: Sage.

Dixon, J., A. Gulliver, and D. Gibbon (2001). Farming systems and poverty: Improving farmer's livelihoods in a changing world. Rome: FAO and Washington, DC: World Bank.

Douthwaite, B. (2002). Enabling Innovation: A Practical Guide to Understanding and Fostering Technological Change. London: Zed Books.

Douthwaite, B., T. Kuby, E. van de Fliert, and S. Schulz (2003). "Impact pathway evaluation: An approach for achieving and attributing impact in complex systems." Agricultural Systems 78: 243-265.

Funtowicz, S. O. and J. R. Ravetz (1993). "Science for the post-normal age." Futures 25(7): 739-775.

Giampietro, M. (2003). Beta-Gamma Science for Sustainable Agriculture: Taking the Implications of Complexity Seriously. $\mathrm{PhD}$ dissertation. Wageningen University, The Netherlands.

Giller, K., N. Koning, and P. Richards (2003). "Bumping along the bottom: The lack of resilience in smallholder African farming." Paper presented at the International Conference on Local Land Use Strategies in a Globalizing World: Shaping Sustainable Social and Natural Environments. August 2003, Copenhagen.

Guba, E. G. and Y. S. Lincoln (1989). Fourth Generation Evaluation. London: Sage. 
Hounkonnou, D., D. Kossou, T. W. Kuyper, C. Leeuwis, P. Richards, N. Röling, O. Sakyi-Dawson, and A. van Huis (2006). "Convergence of Sciences: The management of agricultural research for small-scale farmers in Benin and Ghana." NJAS - Wageningen Journal of Life Sciences 53(3-4): 343-367.

Jiggins, J. and H. de Zeeuw (1992). "Participatory technology development in practice: Process and methods." In C. Reijntjes, B. Haverkort, and A. Waters-Bayer (eds.), Farming for the Future: An Introduction for Low-External Input and Sustainable Agriculture, (pp. 135-162). London: Macmillan and Leusden, Belgium: ILEIA.

Johnson, N. L., N. Lilja, and A. Ashby (2003). "Measuring the impact of user participation in agricultural and natural resource management research." Agricultural Systems 78: 287-306.

Kpaikpai, K. K. (2003). Guide pour la Constitution et la Gestion d'une Banque de Cereals. Togo, West Africa: Institut de Conseil et d'Appui Technique.

Manyong, V. M., A. V. Zoundékon, A. Gogan, M. N. Versteeg, and F. van der Pol (1996). "Determinants of adoption for a resource management technology." In Z. Senwen and W. Yunlong (eds.), Proceedings of Advances in Agricultural and Biological Environment Engineering. August 15-19, (pp. 186-193). Beijing, China: China Agricultural University Press.

Mazzucato, V. and D. Niemeijer (2000). Rethinking Soil and Water Conservation in a Changing Society: A Case Study in Eastern Burkina Faso. PhD. Dissertation, Wageningen University, The Netherlands.

Morss, E. (1976). Strategies for Small Farmer Development: An Empirical Study of Rural Development Projects. Boulder, Colorado: Westview Press.

Mutimba, J. K. (1997). Farmer Participatory Research: An Analysis of Resource-poor Farmer Involvement in, and Contribution to, the Agricultural Research Process in Zimbabwe. PhD dissertation, Faculty of Agriculture, University of Zimbabwe, Harare, Zimbabwe.

Mutsaers, H. J. W., G. K. Weber, P. Walker, and N. M. Fischer (1997). A Field Guide for On-Farm Experimentation. Ibadan, Nigeria: International Institute of Tropical Agriculture.

Nanda, S. (1990). Cultural Anthropology. 4th edition, Belmont, California: Wadsworth Publishing Company.

Nederlof, E. S. (2003). Proposal: Research on Agricultural Research: Enhancing Innovative Performance in Sustainable Land Use Management in West Africa. Case Studies from Ghana and Benin. [Granted by the Dutch Organisation for Scientific Research NWO]. Unpublished report.

Pieri, C. (1989). Fertilité des Terres de Savanes: Bilan de Trente Ans de Développement Agricoles au Sud du Sahara. Paris, France: Ministère de la Coopération et CIRADIRAT.

Pontius, J., R. Dilts, and A. Bartlett (2002). From Farmer Field School to Community IPM: Ten Years of IPM Training in Asia. Bangkok, Thailand: Food and Agriculture Organization of the United Nations, Community IPM Program.

Pound, B., S. Snapp, C. McDougall, and A. Braun (2003). Managing Natural Resources for Sustainable Livelihoods: Uniting Science and Participation. London: Earthscan Publications.
Pretty, J.N. (1994). "Alternative systems of inquiry for a sustainable agriculture." In S. Davies (ed.), Knowledge is Power? The Use and Abuse of Information in Development, (pp. 37-48). Brighton, UK: University of Sussex, Institute of Development Studies.

Pretty, J. N. (1995). Regenerating Agriculture: Policies and Practice for Sustainability and Self-reliance. London: Earthscan.

Pretty, J. N., I. Guijt, I. Scoones, and J. Thompson (1995). A Trainer's Guide for Participatory Learning and Action. London, United Kingdom. International Institute for Environment and Development Brighton, United Kingdom: University of Sussex, Institute of Development Studies, IIED Participatory Methodology Series.

Reijntjes, C., B. Haverkort, and A. Waters-Bayer (1992). Farming for the Future: An Introduction to Low-External Input and Sustainable Agriculture. The Netherlands: ETC and ILEIA.

Rhoades, R. E., and R. H. Booth (1982). "Farmer-back-tofarmer: A model for generating agricultural technology." Agricultural Administration, London: Overseas Development Institute 1: 127-137.

Rogers, E. M. (1995). Diffusion of Innovations. 4th edition, New York: Free Press.

Röling, N. (1988). Extension Science. Cambridge, United Kingdom: Cambridge University Press.

Röling, N. G. and J. Jiggins (1998). "The ecological knowledge system." In N. G. Röling and M. A. E Wagemakers (eds.), Facilitating Sustainable Agriculture: Participatory Learning and Adaptive Management in Times of Environmental Uncertainty, (pp. 283-311). Cambridge, UK: Cambridge University Press.

Röling, N. G., D. Hounkonnou, S. K. Offei, R. C. Tossou, and A. van Huis (2004). "Linking science and farmers' innovative capacity: Diagnostic studies from Ghana and Benin." NJAS - Wageningen Journal of Life Sciences 52: 211-236.

Saïdou, A., T. W. Kuyper, D. Kossou, R. Tossou, and P. Richards (2004). "Sustainable soil fertility management in Benin: Learning from farmers." NJAS - Wageningen Journal of Life Sciences 52: 349-370.

Scheuermeier, U., E. Katz, and S. Heiland (2004). Finding New Things and Ways that Work: A Manual for Introducing Participatory Innovation Development (PID). Lindau, Switzerland: Swiss Center for Agricultural Extension (LBL)..

Steiner, J. L., J. C. Day, R. I. Papendick, R. E. Meyer, and A. R. Bertrand (1988). "Improving and sustaining productivity in dryland regions of developing countries." Advances in Soil Science 8: 79-122.

Stoop, W. A. (2002). A Study and Comprehensive Analysis of the Causes for Low Adoption Rates of Agricultural Research Results in West and Central Africa: Possible Solutions Leading to Greater Future Impacts: The Mali and Guinea Case Studies. Rome: FAO Interim Science Council and CGIAR.

Stoorvogel, J. J. and E. M. A. Smaling (1990). Assessment of Soil Nutrient Depletion in Sub-Saharan Africa: 1983-2000. Volume 1: Main Report. 2nd edition, Wageningen, The Netherlands: The Winand Staring Centre.

Stroosnijder, L. (1992). "Desertification in Sahelian Africa." The Courier 133: 36-39. 
Stroosnijder, L. and T. van Rheenen (eds.) (2001). "Agro-silvo pastoral land-use in Sahelian villages." Advances in Geoecology 33. Catena Verlag, Reichskirchen, Germany.

Swift, J. (1996). "Desertification: Narratives, Winners and Losers." In M. Leach and R. Mearns (eds.), The Lie of the Land: Challenging Received Wisdom on the African Environment: African Issues, Portsmouth, New Hampshire: Heinemann.

Tarawali, G., V. M. Manyong, R. J. Carsky, P. Vissoh, P. OseiBonsu, and M. Galiba (1999). "Adoption of improved fallows in West Africa: Lessons from Mucuna and stylo case studies." Agro-forestry Systems 47: 93-122.

Tekelenburg, A. (2001). Cactus Pear and Cochineal in Cochabamba: The Development of a Cross-epistemological Management Toolkit forIinteractive Design of Farm Innovation. $\mathrm{PhD}$ dissertation. Wageningen University, The Netherlands..

Uvin, P. and D. Miller (1994). Scaling Up: Thinking Through the Issues. New York, New York: Global Policy Forum. Retrieved from http://www.globalpolicy.org/ngos/role/intro/ imp/2000/1204.htm\#1 on December 5, 2003.

van de Fliert, E. (1993). Integrated Pest Management: Farmer Field Schools Generate Sustainable Practices. A Case Study in Central Java Evaluating IPM Training. PhD dissertation, Wageningen University, The Netherlands.

van de Fliert, E. E. and A. R. Braun (2002). "Conceptualizing integrative, farmer participatory research for sustainable agriculture: From opportunities to impact." Agriculture and Human Values 19(1): 25-38. van Schoubroeck F. (1999). Learning to Fight a Fly: Developing Citrus IPM in Bhutan. $\mathrm{PhD}$ dissertation, Wageningen University, The Netherlands..

van Veldhuizen, L., A. Waters-Bayer, and C. Wettasinha (2003). "Advancing PTD: Making our way towards institutional integration." In C. Wettasinha, L. van Veldhuizen, and A. Waters-Bayer (eds.), Advancing Participatory Technology Development-Case studies on Integration into Agricultural Research, Extension and Education, Wageningen, The Netherlands: Technical Centre for Agricultural and Rural Cooperation (CTA)

Vereijken, P. A. (1999). "Methodological way of prototyping integrated and ecological arable farming systems (I/EAFS) in interaction with pilot farms." In C. Leeuwis (ed.), Integral Design: Innovation in Agriculture and Resource Management, Mansholt studies 15, Wageningen/Leiden, The Netherland: Mansholt Institute/Backhuys Publishers.

Werner, J. (1996). Développement Participatif d'Innovations Agricoles: Procedures et Methods de la Recherché en Milieu Paysan. Germany: Deutsche Gesellschaft für Technische Zusammenarbeit (GTZ).

Address for correspondence: Suzanne Nederlof, Julianastraat 78, 6707DH, Wageningen, The Netherlands

Phone: +31-0317420237; Fax: +31-0205688444

E-mail: SuzanneCoS@yahoo.co.uk 